\title{
Chief Digital Officers as Protagonists in Digital Transformation
}

\author{
Jostein Engesmo ${ }^{10000-0002-9468-2369]}$ and Niki Panteli ${ }^{1,2[0000-0003-0822-3842]}$ \\ ${ }^{1}$ Department of Computer Science, Norwegian University of Science and Technology, Sem \\ Saelandsvei 9, 7491 Trondheim, Norway \\ ${ }^{2}$ School of Management, Royal Holloway, University of London, Egham, TW20 0EX Surrey, \\ UK \\ jostein.engesmo@ntnu.no niki.panteli@rhul.ac.uk
}

\begin{abstract}
With the popularity of digital transformation programmes becoming widerspread, our study is motivated by a need to understand who has the responsibility for digital transformation across different types of organisations and industries. We take a specific focus on the Chief Digital Officer which has been considered the most fast growing executive role in the recent years. In particular, in this paper, we present a research in progress study that aims to examine the role of Chief Digital Officer in enabling digital transformation in traditional, predigital organisations, and to identify its impact on the IT department of these organisations. The empirical study is based on the qualitative approach with its main dataset deriving from a series of semi-structured interviews. The study is expected to have both theoretical and practical implications on the management of digital transformation.
\end{abstract}

Keywords: Digital Transformation, Digital Technologies, Chief Digital Officer, Chief Information Officer, Leadership.

\section{Introduction}

Digital transformation has been receiving an overwhelming attention by both academics and practitioners alike. While on the one hand, organisations such as digital startups are born with and because of digital technologies, known as born-digital, on the other hand, traditional, pre-digital, organisations have to find ways to embrace digital transformation into their operations and strategies whilst overcoming structural and cultural barriers. Reports have placed digital transformation high up on the business agenda [1]. In this paper we are interested in investigating the role of the Chief Digital Officer (CDO) in digital transformation, a fast growing role in the executive management team of many organisations [2], the impact that this role has on the transformation programme as well as on the IT department of the organisation.

In what follows, we review literature on digital transformation exploring the opportunities and challenges it provides to pre-digital organisations. We then discuss the role of Chief Information Officers (CIOs) who have traditionally been expected to lead ITenabled change in organisations and introduce the emerging role of CDOs. Following these, we introduce the research design of the study and its expected contributions. 


\section{$2 \quad$ Literature Review}

\subsection{Digital Transformation: Concept, Opportunities and Challenges}

With the emergence of digital technologies that encompass smart and interconnected systems, and the popularity of artificial intelligence, digital platforms, cloud computing, social media, as well as big data and data analytics [3], an increasing literature exists on the potentials of these technologies in transforming organisations. For example, the adoption of artificial intelligence creates new opportunities and challenges for employees and organisations by automating, transforming and possibly augmenting work and work boundaries, control, coordination and expertise [4, 5]. Further, the opportunities of platforms and platformisation tend to cross organisational boundaries where network of actors (including platform owners and customers) together create value $[6,7]$. Further, empirical studies have examined the role of digital platforms in promoting digital transformation among SMEs [8]. Many of the important innovations within digital technologies build on cloud computing [9], and with prior focus on cost reduction, cloud computing now also provides strategic impact [10]. Summing up research within business intelligence and analytics, it is evident that studies increasingly focus on big data $[11,12]$. One opportunity arising here is for businesses to analyse data, including unstructured data, from use of social media and an increasing amount of sensors [13]. Lastly, studies of social media adoption points to both potential use internally $[14,15]$ and externally [16], as well as how to succeed with the adoption process [17]. Accordingly, digital transformation programmes often encompass a wide range of technologies adding to their complexity and challenges whilst opening up a range of opportunities for the organisations involved.

Different definitions have been given to digital transformation. Table 1 captures some of these definitions:

Table 1. Definitions of Digital Transformation.

\begin{tabular}{ll}
\hline Sources (in chronological order) & Definition \\
\hline Bharadwaj, Sawy, Pavlou, \& Ven- & $\begin{array}{l}\text { Increasing scope and scale of digital business strategy, } \\
\text { speed of decision making, and sources of value crea- } \\
\text { katraman [18] }\end{array}$ \\
tion and capture \\
Westerman, Bonnet, \& McAfee & $\begin{array}{l}\text { The use of technology to radically improve perfor- } \\
\text { mance or reach of enterprises }\end{array}$ \\
[19] & The application of digital technologies to fundamen- \\
Gruman [20] & tally impact all aspects of business \\
& Employing machine, platform, crowd and rebalance \\
McAfee \& Brynjolfsson [3] & with human mind, product, core
\end{tabular}




\author{
Chianas, Myers \& Hess [21]
}

Hinings, Gegenhuber \& Greenwood [22]

Vial [23]
A holistic form of business transformation enabled by information systems (IS) that is accompanied by fundamental economic and technological changes at both the organizational and industry-level

The combined effects of several digital innovations bringing about novel actors (and actor constellations), structures, practices, values, and beliefs that change, threaten, replace or complement existing rules of the game within organizations and fields.

A process where digital technologies create disruptions triggering strategic responses from organizations that seek to alter their value creation paths while managing the structural changes and organizational barriers that affect the positive and negative outcomes of this process.

It follows from the table above that though some definitions on digital transformation have given an emphasis on the use and application of digital technologies, others have taken a broader focus that includes a strategic perspective of digital innovations and their impact on the wider business context and beyond. Siebel [24] posited that digital transformation is all about change, including change in the way products are designed all the way to how products are serviced. According to Cascio and Montealerge [25], the implications include: “...transforming the very foundations of global business and the organizations that drive it [...] not just helping people to do things better and faster, but they are enabling profound changes in the ways that work is done in organizations" (p. 350). Digital transformation strategies are found to have dimensions of use of technologies, changes in value creation, structural changes and financial aspects, where the latter is necessary for the others to take place [26]. With these, digitalization transforms business models, operational processes and user experience [27].

Studies exist on the vital role that digital transformation plays in revamping organisations whilst also identifying the different dimensions of digital transformation [19] as well as how they gain wider stakeholders' approval and become institutionalised [22]. Westerman and Bonnet [28] posit that large traditional organisations need to rethink key managerial assumptions they often have about the type of customer service they offer, extend the automation and integration of their operations and their pre-digital strategic assets. In their view, these pre-digital assumptions may constrain developments in digital initiatives and therefore act as challenges in their implementation, and need to be revisited and adjusted in order to effectively embrace digital transformation. As such, according to Kane et al. [29], digital transformation should be guided by a business digital strategy as well as an organisational culture that encourages innovation and collaboration. Leadership has also been found to be another key factor for successfully transforming an organisation to being a digital organisation [30]. In this paper, we extend research in this area by taking a specific focus on the leadership of digital transformation programmes. It is our position that the nature of digital transformation that 
radically integrates digital technologies in business initiatives, processes and structures calls for a change in IT leadership to one that is a digital business integrator and not just an IT manger. For this, we examine the role of chief digital officers, a fast growing role in the senior management of numerous pre-digital organisations.

\subsection{Chief Information Officers and Chief Digital Officers}

Traditionally, IT-driven business change was a responsibility of the IT department and the Chief Information Officer (CIO). This was supported by an increasing acknowledgement in the information systems literature that the long term sustainable business value of IT resides in its complementarity and integration with business strategies, structures and competences [31]. According to Willcocks et al. [32] the IT department has four primary tasks which include: ensuring technical capability, managing external supply, eliciting and delivering on business requirements and IS governance and leadership. These tasks, which are inter-linked, contribute to nine associated core IT capabilities with IT leadership as the central one and ranging from architecture planning, IT implementation, business systems thinking, relationships building and vendor development.

Despite these capabilities and responsibilities linked to CIOs, recent research has posited that CIOs have not managed to gain strategic leadership positions in their organisations [33] as their role is perceived to be more technology rather than businessorientated. A study of time management for CIOs showed that the main priority for most CIOs is ensuring delivery of infrastructure, applications and projects, and that this makes it difficult to spend as much as time as they would like on more strategic activitites [34]. This may therefore explain the emerging role of CDOs in leading companywide digital transformation programmes.

According to an industry report, the role of CDOs presents the organisation's intention to embrace digital transformation [35]. Extant literature has emphasized the strategic involvement of CDOs in creating and implementing digital transformation projects. Further, according to a McKinsey report [36], the role should be given to someone who has obsession with the customer. Similarly, Horlacher and Hess [37] found that the CDOs they studied exhibit a strong customer focus and have an aim not just to improve but personalise customer experience.

Tumbas et al. [38] find that CDOs intentionally emphasize their skills and expertise in 'digital' as a way for distinguishing themselves from other senior management. They do so in order to gain legitimacy and strengthen their identity within the organisation. In this study, CDOs were also found to view the IT department as having more operational and cost saving function as opposed to their own role who they perceive as more revenue enhancing, transformational and customer facing. Singh and Hess [39] have also described CDOs as entrepreneurs who are highly customer focused, digital evangelists who are disseminating the digital strategy across the organisation, and crossfunctional coordinators as they are expected to inter-link the whole company with digital technologies. Therefore apart from IT competency which is a critical skill for CDOs, these post-holders should also show competency in change management skills, digital pioneering and inspiration skills (ibid). 
In this paper, we adopt Goffman's [40] dramaturgical analogy which named roles in organisations according to the most common characters in a play: protagonists (the leading character in a play), deuteragonists (secondary character with supporting role), tritagonists (minor character). Accordingly, we view CDOs as protagonists for digital transformation in their organisations. As leading figures, CDOs are expected to be on central stage, take decisions and follow these through to their implementation.

Two research questions are driving the study: First, how is the role of Chief Digital Officers enabling digital transformation in traditional pre-digital organisations? And, second: How is the role of CDOs changing IT departments and IT leadership?

\section{$3 \quad$ Research Design and Initial Findings}

Our research approach comprises of an exploratory qualitative approach and includes two phases. Phase 1 of our data collection, involved the collection of job adverts of CDOs and related posts (e.g. Head of Digital, Digital Director) across different industries. LinkedIn was used for this purpose for a two month period (mid March- mid May) with the aim to understand the qualifications, experience and requirements of the role in different organisations and industries.

Phase 2, which will be taking place in early summer 2019, involves a series of semistructured interviews with CDOs and CIOs across a selection of organisations. Particular emphasis in the interviews will be paid on the strategic role of each of these roles and their inter-relationships and the influence they exert or are expected to exert on each other. Thematic analysis will serve as our analytical approach. Data will be collected in both UK and Norway by both authors.

In Phase 1, we collected 25 adverts which were from a variety of industries and encompassed both public and private firms as well as large corporates (e.g. construction and media companies) and independent organisations (e.g. hotel boutiques and fashion houses). Tentative findings present CDOs as protagonists, though the nature of the transformation initiative may vary from strategic to marketing and technology. Our analysis show that public sector organizations tend to give a strategic focus to the position, expecting the person in the role to drive forward the digital transformation process/programme. Private companies, maybe due to being better resourced in terms of digital knowhow and capability, tend to give a narrower focus to their CDOs, often being linked to digital marketing and content management. Also where CDOs are expected to drive forward the strategic transformation of the organisation, there is also the expectation for them to work closely with other executives especially in marketing and IT and provide digital transformation technical leadership. Overall, what we can see is that emphasis on strategic direction varies across the different sectors covered in the job adverts.

\section{$4 \quad$ Research Design and Initial Findings}

This far, we have conducted a literature review in the areas of digital transformation, CIOs and CDOs in order to develop our research questions, and we have also started to 
collect data. At the time of the conference we will be presenting the initial results of both Phase 1 and 2 of our empirical study.

We expect to contribute to the Information systems literature with this research-inprogress paper, and in particular to the literature on digital transformation. Our study has implications for the management and leadership of digital transformation programmes as well as for IT departments which we will present at the conference.

\section{References}

1. Hess, T., Matt, C., Benlian, A., Wiesböck, F.: Options for formulating a digital transformation strategy. MIS Quarterly Executive. 15(2), 123-139 (2016).

2. Grossman, R., Rich, J.: The rise of the chief digital officer. Russell Reynolds Associates (2012).

3. McAfee, A., Brynjolfsson, E.: Harnessing Our Digital Future. Machine, Platform, Crowd. W. W. Norton \& Company Ltd (2017).

4. Barrett, M., Oborn, E., Orlikowski, W. J., Yates, J.: Reconfiguring Boundary Relations: Robotic Innovations in Pharmacy Work. Organization Science. 23(5), 1448-1466 (2012). doi: 10.1287/orsc. 1100.0639

5. Faraj, S., Pachidi, S., Sayegh, K.: Working and organizing in the age of the learning algorithm. Information and Organization. 28(1), 62-70 (2018). doi: 10.1016/j.infoandorg.2018.02.005

6. Constantinides, P., Henfridsson, O., Parker, G.: Introduction - Platforms and Infrastructures in the Digital Age. Information Systems Research. 29(2), 381-400 (2019). doi: 10.1287/isre.2018.0794

7. Henfridsson, O., Nandhakumar, J., Scarbrough, H., Panourgias, N.: Recombination in the open-ended value landscape of digital innovation. Information and Organization. 28(2), 89100 (2018). doi: 10.1016/j.infoandorg.2018.03.001

8. Li, L., Su, F., Zhang, W., Mao, J. Y.: Digital transformation by SME entrepreneurs: A capability perspective. Information Systems Journal. 28(6), 1129-1157 (2018). doi: 10.1111/isj.12153

9. Henriette, E., Feki, M., Boughzala, I.: The Shape of Digital Transformation: A Systematic Literature Review. In: MCIS2015 Proceedings, 10 (2016).

10. Junior, A., Biancolino, C., \& Maccari, E.: Cloud Computing and Information Technology Strategy. Journal of Technology Management \& Innovation. 8, 178-188 (2013). doi: 10.4067/S0718-27242013000300070

11. Chen, Hsinchun, Roger H. L. Chiang, V. C. S.: Business Intelligence and Analytics: From Big Data to Big Impact. MIS Quarterly. 36(4), 1165-1188 (2012). doi: $10.1145 / 2463676.2463712$

12. Gandomi, A., Haider, M.: Beyond the hype: Big data concepts, methods, and analytics. International Journal of Information Management. 35(2), 137-144 (2015). doi: 10.1016/j.ijinfomgt.2014.10.007

13. Brynjolfsson, E., McAfee, A.: Big Data: The Management Revolution. Harvard Business Review. October, 1-12 (2012). doi: 10.1007/978-3-319-05029-4

14. Leonardi, P. M., Huysman, M., Steinfield, C.: Enterprise Social Media: Definition, History, and Prospects for the Study of Social Technologies in Organizations. Journal of ComputerMediated Communication. 19(1), 1-19 (2013). doi: 10.1111/jcc4.12029

15. Kane, G. C.: The Potential of Enterprise Social Media. MIS Quarterly Executive. 14(1), 116 (2015). doi: 10.1111/jcc4.12029 
16. Effing, R., Spil, T. A. M.: The social strategy cone: Towards a framework for evaluating social media strategies. International Journal of Information Management. 36(1), 1-8 (2016). doi: 10.1016/j.ijinfomgt.2015.07.009

17. Nolte, F., Guhr, N., Breitner, M. H.: Moderation of Enterprise Social Networks - A Literature Review from a Corporate Perspective. In: Proceedings of the 50th Hawaii International Conference on System Sciences, pp. 1964-1973. (2017). doi: 10.24251/HICSS.2017.238

18. Bharadwaj, A., Sawy, O. A. El, Pavlou, P. A., Venkatraman, N.: Digital Business Strategy: Toward a Next Generation of Insights. MIS Quarterly. 37(2), 471-482 (2013).

19. Westerman, G., Bonnet, D., McAfee, A.: The nine elements of digital transformation. MIT Sloan Management Review. 55(3), 1-6 (2014).

20. Gruman, G.: What digital transformation really means. InfoWorld (2016). http://www.infoworld.com/article/3080644/it-management/what-digital-transformation-reallymeans.html

21. Chanias, S., Myers, M. D., Hess, T.: Digital transformation strategy making in pre-digital organizations: The case of a financial services provider. The Journal of Strategic Information Systems. 28 (1), 17-33 (2018). Doi: 10.1016/j.jsis.2018.11.003

22. Hinings, B., Gegenhuber, T., Greenwood, R.: Digital innovation and transformation: An institutional perspective. Information and Organization. 28(1), 52-61 (2018). doi: 10.1016/j.infoandorg.2018.02.004

23. Vial, G.: Understanding digital transformation: A review and a research agenda. Journal of Strategic Information Systems. Forthcoming (2019). doi: 10.1016/j.jsis.2019.01.003

24. Siebel, T. M.: Why digital transformation is now on the CEO's shoulders. McKinsey Quarterly. 4(3), 1-7 (2017).

25. Cascio, W. F., Montealegre, R.: How Technology Is Changing Work and Organizations. Annual Review of Organizational Psychology and Organizational Behavior. 3(1), 349-375 (2016). doi: 10.1146/annurev-orgpsych-041015-062352

26. Matt, C., Hess, T., Benlian, A.: Digital Transformation Strategies. Business and Information Systems Engineering. 57(5), 339-343 (2015). doi: 10.1007/s12599-015-0401-5

27. Henriette, E., Feki, M., Boughzala, I.: The Shape of Digital Transformation: A Systematic Literature Review. In: MCIS2015 Proceedings, 10 (2016).

28. Westerman, G., Bonnet, D.: Revamping your business through digital transformation. MIT Sloan Management Review. 56(3), 10 (2015).

29. Kane, G. C., Palmer, D., Phillips, A. N., Kiron, D., Buckley, N.: Strategy, not technology, drives digital transformation. MIT Sloan Management Review and Deloitte University Press. 14, 1-25 (2015).

30. Kontić, L., Vidicki, Đ.: Strategy for digital organization: Testing a measurement tool for digital transformation. Strategic Management. 23(1), 29-35 (2018). doi: 10.5937/StraMan1801029K

31. Sambamurthy, V.: Shaping agility through digital options: reconceptualizing the role of information technology in Contemporary firms. MIS Quarterly. 27 (2), 237-263 (2003). doi: $10.2307 / 30036530$

32. Willcocks, L., Reynolds, P., Feeny, D.: Evolving IS Capabilities to leverage the external IT Services Market. MIS Quarterly Executive. 6(3), 127-145 (2007).

33. Gonzalez P., Ashforth, L., McKeen, J.: The CIO stereotype: Content, bias, and impact. Journal of Strategic Information Systems. 28, 83-99 (2019). doi: 10.1016/j.jsis.2018.09.002

34. Weill, P., \& Woerner, S. L. The Future of the CIO in Digital Economy. MIS Quarterly Executive, June, 65-76 (2013).

35. CIO.: Why the chief digital officer role is on the rise. (2013) http://www.cio.com/article/2380788/careers-staffing/why-the-chief-digital-officer-role-is-on-the-rise.html 
36. Rickards, T., Smaje, K., Sohoni, V.: Transformer in chief': The new chief digital officer. (2015) http://www.mckinsey.com/business-functions/organization/our-insights/transformer-in-chief-the-new-chief-digital-officer

37. Horlacher, A., Hess, T.: What does a Chief Digital Officer do? Managerial tasks and roles of a new C-level position in the context of digital transformation. In: 2016 49th Hawaii International Conference on System Sciences (HICSS), pp. 5126-5135. IEEE (2016). doi: 10.1109/HICSS.2016.634

38. Tumbas, S., Berente, N., Brocke, J. V.: Digital innovation and institutional entrepreneurship: Chief Digital Officer perspectives of their emerging role. Journal of Information Technology. 33(3), 188-202 (2018). doi: 10.1057/s41265-018-0055-0

39. Singh, A., Hess, T.: How Chief Digital Officers Promote the Digital Transformation of their Companies. MIS Quarterly Executive. 16(1), 1-17 (2017).

40. Goffman, E.: The Presentation of Self in Everyday Life. Garden City, NY: Doubleday Anchor (1959). 